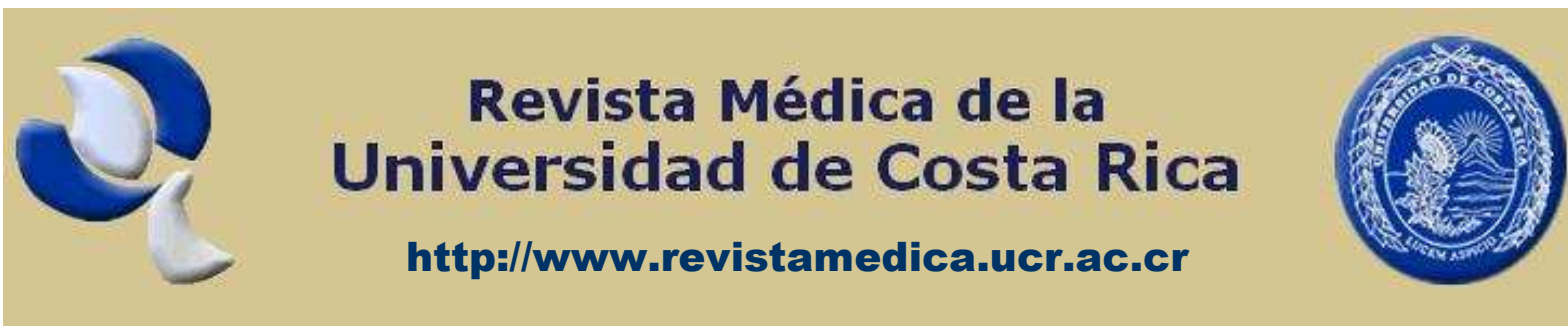

\title{
Conversatorio
}

\section{CONVERSACIONES CON LUIS PASTEUR}

\section{Jaramillo Antillón, Juan}

Catedrático de la Escuela de Medicina y Profesor Emérito de la Universidad de Costa Rica, San Pedro, San José, Costa Rica.

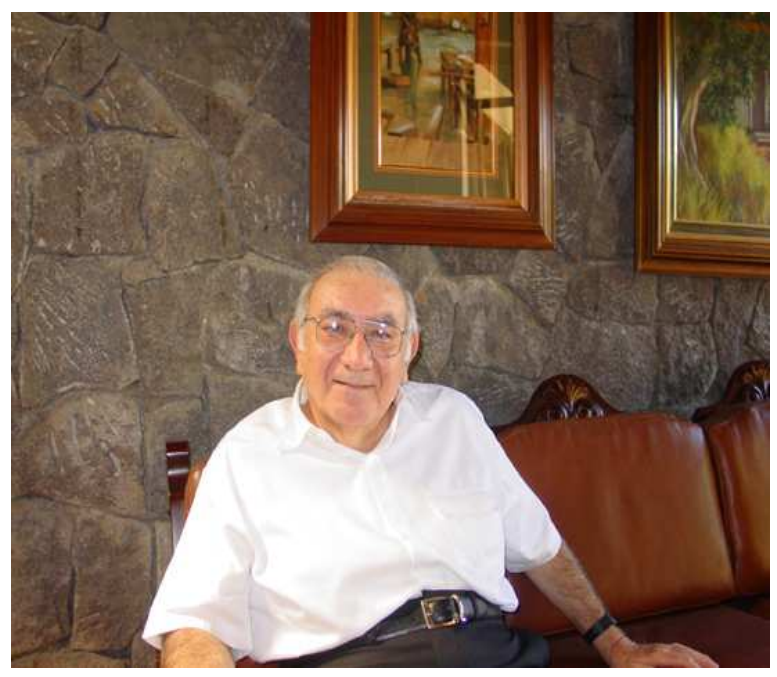

CONVERSACIONES CON EL DR. JUAN JARAMILLO ANTILLON

Recibido: Agosto 2009. Aceptado: Septiembre 2009. Publicado: Septiembre 2009.

P: Donde nació usted y en qué año. R: El 27 de Diciembre de 1822, en el pequeño pueblo de Arbois en Francia. Mi padre era curtidor de cueros. P: Donde estudio. R: La primaria la realicé en dicho pueblo. P: Usted se consideraba genial. R: No, durante mis primeros quince años de vida no mostré ningún espíritu de investigación o alguna genialidad, aparte de hacer retratos, era un hábil dibujante y retratista y pinté a toda mi familia, me pasaba pescando. La familia se trasladó a Bensacon $\mathbf{y}$ ahí, en el Real Colegio me 
gradué de bachiller en 1840. Mis profesores lo único que vieron positivo en mí fue que ayudaba a mis compañeros en sus estudios. P: Donde estudió su profesión. R: En la escuela normal superior de París en los campos de la Física y la Química y en 1847 obtuve un doctorado en Ciencias. P: Usted no se graduó de médico. R: No.

P: Cual considera que fue su primer paso para darse a conocer. R: Yo trabajaba como asistente de química en la Universidad de Estrasburgo. Ahí postulé el efecto óptico a que daban lugar los rayos polarizados. Aunque se creía que los cristales del ácido tartárico desviaban hacia la derecha el plano de la luz polarizada y por eso se le calificaba de dextrogira, existía otro tipo de ácido idéntico pero levogira; es decir que desviaba la luz a la izquierda, ese fue mi primer descubrimiento.

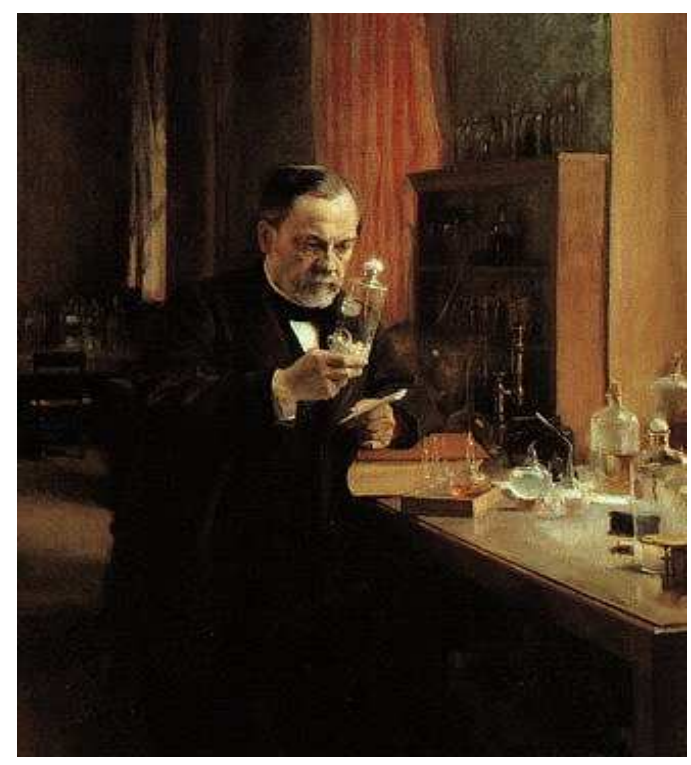

Luis Paster. Tomado de: www.google.co.cr/imgres?imgurl=http://2.bp.blo gspot.com
P: Se dice que a usted le ayudo mucho en su carrera el que en 1849 contrajera matrimonio con Marie Laurent, hija del rector de la Universidad de Lille. R: Es cierto con ella y tuve una gran compañera y esposa, me dio cinco hijos, y durante toda mi carrera madame Pasteur me ayudó escribiendo los trabajos científicos le dictaba para enviar a las academias y a publicaciones, ya que tenía una excelente caligrafía. P: Bueno yo me refería más a que académicamente ese matrimonio lo impulsó a usted. R: También es cierto, ya que gracias a esa relación me conocieron ahí y trabajé en dicha Universidad hasta llegar a Decano de la Facultad de Ciencias. P: Realizó ahí algún trabajo importante. R: Ahí inicié mis trabajos sobre el alcohol amílico que me llevaría más tarde a estudiar la fermentación en especial del ácido láctico, la de la leche, y la fermentación alcohólica de vinos, cervezas e incluso del vinagre. P: Tengo entendido que a usted los industriales de la región le dieron mucha ayuda económica y le ayudaron a crear un laboratorio de investigación. R: Correcto, ellos querían elevar el rendimiento en azúcar de la remolacha para poder producir más alcohol, algo que logré.

P: Posiblemente pocas personas han contribuido tanto al progreso de la medicina y la industria para beneficio de la humanidad que usted. R: Yo senté las bases sobre las que se fundó la microbiología junto con Roberto Koch, y en medicina, di lugar a la teoría sobre las enfermedades provocadas por gérmenes. Gracias a mí se reconoció la capacidad del aire para transportar gérmenes $y$ bacterias, vivas capaces de contaminar el mosto o la cerveza o a personas. P: Otros hechos: R: Yo describí que existían gérmenes anaerobios que vivían si 
necesidad del aire y otros aerobios. Fui el creador de la pasteurización que consiste en el calentamiento de vinos o de leche durante 30 minutos a 68 grados centígrados y con ello se destruyen esporas y gérmenes capaces de producir enfermedades y sin que se destruyan las proteínas de la leche y el sabor de esta y el vino, con ello se evitaron enfermedades en los niños lactantes.

P: Se dice que usted era muy egoísta, ya que llegó a demostrar que las levaduras eran un microorganismo unicelular de la familia de los hongos Saccharomyces cerevisiae, la cual convertía el azúcar en alcohol y aceptó el éxito de ese reconocimiento, sin citar que esta idea ya había sido afirmada anteriormente por el Dr. Teodoro Schwan. R: Es cierto, además yo descubrí el bacilo del carbunco que afecta al ganado vacuno e incluso al hombre, y Robert Koch de Alemania también lo descubrió y estudió al mismo tiempo. Pero yo desconocía esos hechos de ambos.

P: Otros descubrimientos. R: Descubrí el estafilococo de los abscesos de la piel, y inventé la vacuna contra la rabia. En ese tiempo pensé que la rabia era producida por un bacilo tan pequeño que no era posible verlo al microscopio y tenía razón, ya que posteriormente se comprobó que era un virus y estos no son visibles con los microscopios corrientes. Fui el primero en establecer una conexión definitiva entre los microorganismos y la aparición de enfermedades. Señalé que muchas bacterias pululan en el aire y contaminan el medio, y que esas mismas bacterias no podrían producirse por generación espontánea. Además, se dio cuenta que al someterlas a la acción del calor, pierden su capacidad, posiblemente por perecer.
P: El famoso cirujano inglés Lord Joseph Lister, comprendió el extraordinario valor de su descubrimiento y creo la antisepsia con sumersión de todo el instrumental quirúrgico antes de una operación en ácido fenólico y el lavado de las manos con un detergente y con ello las infecciones de las operaciones descendieron notablemente. R: Yo había ayudado así al avance de la cirugía.

P: Descubrió usted los gérmenes anaerobios como dijo antes. R: Cuando estudie la fermentación butírica, descubrí el carácter anaeróbico de algunos gérmenes de esta fermentación, ya que no necesitaban oxígeno para vivir. Introduje entonces el concepto en bacteriología de gérmenes aerobios y anaerobios. P: Pero ya anteriormente Leeuwenhoek inventor del microscopio y cien años antes Spallanzani, habían señalado la existencia de animalitos microscópicos que no necesitaban del aire para vivir. R: Yo desconocía esos hechos. P: Pero como en este $\mathrm{y}$ otros casos usted no le dio reconocimiento a otros antecesores suyos, que se adelantaron en sus conceptos, queda la duda de si desconocía o no dichos trabajos. Un gesto muy mezquino de un investigador tan grande. R: Insisto en que no sabía nada.

P: Papel en la educación. R: De hecho, revolucione la educación, al combinar la teoría con la práctica llevando a mis alumnos a trabajar en el laboratorio y en sus investigaciones, teoría sin práctica es inútil. Los alumnos no sólo escuchaban mis conferencias magistrales, sino que colaboraban en el laboratorio experimental donde trabajaba yo, permitiéndoles participar en algunas de las investigaciones $\mathrm{e}$ incluso hacer 
demostraciones de los resultados obtenidos, lo cual los motivaba.

P: Debido a su prestigio en 1857 fue nombrado director de estudios científicos de la Escuela Normal Superior de Paris, donde permaneció hasta 1863. R: Correcto, pero pese a mi prestigio tenía laboratorios muy deficientes y yo logré que la empresa privada y el gobierno contribuyeran para crear excelentes laboratorios de investigación. Ahí realice estudios que demostraron que los microbios no nacen espontáneamente en el interior de las uvas, los gusanos de seda, la orina o la sangre, siempre vienen del exterior y contaminan a las plantas, animales o personas.

P: Por qué se le considera precursor de la inmunología. R: Junto a Eduardo Jenner, creador de la vacuna contra la viruela, y mis vacunas dimos principio a esta rama de la ciencia. P: Es cierto que no aceptaba críticas, fueran estas correctas o no y usualmente era agresivo en sus respuestas lo que ocasionaba polémica a su alrededor. R: Lamentablemente si. P: A propósito de egoísta, a sus fieles ayudantes Duxlaus y Gernez, quienes colaboraron con usted en el proceso de pasteurización y por años en el estudio de los gusanos de la seda, no les participó del éxito y ni siquiera los citó como colaboradores. R: Es cierto, pero entre mis alumnos tuvo figuras a los que ayudé a obtener fama mundial: Metchnikoff, Roux, Yersin, Calmett, descubridores de bacterias o vacunas. P: Su máxima. R: " $L a$ casualidad favorece a una mente adiestrada". P: Usted fue elegido miembro de la Academia de Medicina de Francia, un honor que usualmente sólo se concedía a médicos de altos méritos y usted no lo era. R: En 1845 me gradué de doctor en
Física y Química y posteriormente obtuvo un doctorado en Ciencias como ya lo señalé, pero mis investigaciones ayudaron a la medicina a superar muchos problemas.

P: Como se inició en el estudio de la rabia en los humanos. R: Por un niño en mi pueblo que pereció por tal causa en medio de terribles sufrimientos. P: Como inició sus trabajos. R: Extrayendo de la medula espinal de perros rabiosos un fragmento de esta y preparando extractos que eran inoculados al cuerpo de un perro sano, los cuales a los días contraían la enfermedad. Al principio creí que era una bacteria la causante ya que la había encontrado en la boca de un niño con rabia, sin embargo, mis ayudantes Roux y Chamberland descubrieron que el microbio estaba en la boca de muchas personas sanas. Entonces puse saliva de un perro rabioso en el cerebro de un conejo y obtenía un virus (en esa época no se conocían con este nombre) muy virulento que poco a poco lo fui haciendo menos agresivo $y$ al cultivarlos los atenué y con ellos inyecté perros sin que a estos les diera la rabia, o sea, se volvían inmunes a la mordedura de perros rabiosos. P: Que supuso usted provocaba la rabia. R: Yo señalé que la rabia era causada por un agente infeccioso tan pequeño que no era posible verlo al microscopio, como se veían las bacterias o bacilos. Pero a pesar de eso pude desarrollar una vacuna contra un agente infeccioso que no podía ver. No fue sino hasta 1897 cuando el bacteriólogo holandés Martinus W. Beijerinck señaló que el agente transmisor de la enfermedad del tabaco era un "virus filtrable" que no se podía ver ni cultivar.

P: Usted es religioso. R: Sí, soy profundamente religioso. Yo considero 
feliz al hombre que lleva dentro de sí a Dios y le obedece. Feliz si tiene en si un ideal de la belleza, del arte, de la ciencia y de las virtudes del evangelio.

P: Usted no soportaba bien la crítica. R: Cierto, yo era muy serio y sufría mucho con las críticas que se me hacían fueran estas correctas o no. P: Pero usted se las buscaba ya que era muy agresivo en las discusiones científicas y su carácter tenía tendencia a la polémica. P: Usted creo el término vacuna. R: Sí, este viene de vacca en latín, y lo hice en honor de Jenner el creador científico de la vacuna contra la viruela.

P: Usted descubrió el bacilo del cólera de las gallinas y desarrolló técnicas de cultivo in Vitro de microorganismos; para con ello obtener material para sus vacunas. R: Correcto, yo había observado que cultivos viejos (atenuados) de gérmenes de cólera de gallinas, inoculadas a gallinas sanas, no le producían enfermedad, se hacían inmune o resistentes al cólera; con ello contribuí a evitar las epidemias de este tipo en las aves. De hecho este fue un primer paso para que en la actualidad, se emplearan cultivos vivos atenuados 0 muertos por el calor para obtener vacunas contra diferentes enfermedades. A esto se le llamó "inmunización activa”.

Muy bien, muchas gracias don Luis por su conversación.

NOTA: En honor de él se creó el Instituto Pasteur en Paris, de fama mundial y del cual fue director hasta su muerte en 1895. En su discurso final en la Universidad de la Sorbona, al serle entregada una medalla por el Presidente de Francia, pronunció estas palabras que posteriormente los políticos incluso el presidente Kennedy de Estados Unidos han usado y que dicen.

"A medida que progreséis, preguntaos: ¿Qué habéis hecho por tu patria? Entonces, si habéis contribuido de alguna manera al progreso, tendréis una íntima satisfacción".

\section{REFERENCIAS}

Bird, Randy and Allen, Garland. Luis Pasteur. Enciclopedia Encarta 98, Mycrosfot USA, 1998.

Dubos, Rene. J. Luis Pasteur: Freelance of Science. Oxford University Press, England. 1950

Garrison, H. Fielding. Luis Pasteur. En. Historia de la Medicina. Editorial Interamericana S. A. México. 386-390, 1966.

Jaramillo, A. Juan. Luis Pasteur. El más humano de los genios. En. Lo humano de los Genios. Editorial Universidad de Costa Rica. San José. 2005-220, 2003.

Singer, Charles y Ashwort, Underwood. La obra de Pasteur. En. Breve Historia de la Medicina. Ediciones Guadarrama. Madrid, Cap. VII, 325-334, 1966.

Valery-Radot, R. Life of Pasteur. Devonshire Publication. London, 2 Vol. 1902.

\section{"La amistad está basada en la tolerancia"}

Juan Jaramillo Antillón. 